\title{
Correlated Response in Growth Potentiality, Tillering Capacity, and Leafiness of Barseem Clover "Trifolium alexandrium, $L$ " following Selection for Frequent -Cutting Tolerance
}

\author{
M. Abd El-Sattar Ahmed ${ }^{1 *}$, Asmaa M.S. Rady ${ }^{1^{* *}}$, T. K. Abd El-Azize ${ }^{2}$, and W.M. Eldebeky ${ }^{3}$ \\ ${ }^{1}$ Crop Science Dept., Faculty of Agriculture (El-shatby), Alexandria University. \\ *(mohamed.A@alexu.edu.eg). ***(asmaa.mohamed@alexu.edu.eg). \\ ${ }^{2}$ Head Research, Forage Crops Section, ARC, Giza, Egypt. \\ ${ }^{3}$ Post-graduate student, Crop Science Dept., Faculty of Agriculture (El-shatby), Alexandria University.
}

\begin{abstract}
The main objective of the recent study was to trace barseem clover "Trifolium alexandrium, L" landraces with potential resistance to frequent cutting stress. Cumulative correlated realized gains in plant height over cuttings due to first cycle $\left(C_{1}\right)$ of selection for frequent cutting tolerance relative to base population $\left(C_{0}\right)$ reached $2.94,16.84$ and $36.73 \%$ when evaluated under infrequent, frequent and very- frequent cutting regimes, respectively. The first cycle of selection for frequent-cutting tolerance $\left(\mathrm{C}_{1}\right)$ gave a correlated positive improvement in stem girth reached $15.22 \%$ of the respective base population mean, over cutting regimes. Meanwhile, the second cycle $\left(\mathrm{C}_{2}\right)$ added another positive correlated improvement in stem girth reached $13.12 \%$ of first cycle's mean. Also, a correlated realized gains in stem girth due to selection for frequent cutting tolerance relative to the average of check varieties, reached 17.65 and $43.95 \%$ for cycles one $\left(\mathrm{C}_{1}\right)$ and two $\left(\mathrm{C}_{2}\right)$ respectively. Correlated realized gains in leaves weight. Plant ${ }^{-1}$ of the first cycle $\left(\mathrm{C}_{1}\right)$ following selection for frequent cutting tolerance, reached $53.34,106.7$ and $31.37 \%$ relative to the base population, when evaluated under infrequent, frequent and very frequent cutting regimes, respectively. Meanwhile, the substantial correlated realized gains after the second cycle of selection $\left(\mathrm{C}_{2}\right)$ reached $31.79,23.93$ and $10.53 \%$ of first cycle's $\left(\mathrm{C}_{4}\right)$ mean, when evaluated under infrequent, frequent and very frequent cutting regimes, respectively. Over the studied cutting regimes, selected populations gave similar leaves/ stem ratio (fresh weight) ( 27.24 and $30.81 \%$ for $C_{1}$ and $C_{2}$, respectively). Those values were not different from any of the evaluated check varieties.
\end{abstract}

Key words: Barseem clover, correlated response, growth potentiality, tillering, leafiness.

\section{INTRODUCTION}

Breeding barseem clover for frequent cutting tolerance can be defined as breeding to achieve acceptable balance between persistence, quality, yield and animal's safety (Sewell and Reich 2011). Identifying a specific plant type then applying selection program is essential to reach a frequentcutting tolerant population (Annicchiarico et.al, 2010). Breeding for frequent-cutting tolerance depending on single character is though insufficient. Since, frequent-cutting tolerance is considered as a complex character that includes many morphological and physiological traits, along with their interactions with environment (KatepaMupondwa, et.al, 2002). Moreover, it is well know that selection for one trait or many traits related to frequent- cutting tolerance might lead to reduction of productivity and loss or other quality characters (Smith et.al, 2000).In white clover "Trifolium repens, L." Frequent-cutting tolerant genotype had morphological character correlated with stolon diameter, branching potentiality, leaf size and root structure (Ayres et.al,1996; Jahufer et.al,2002, Sanderson et.al,2003, Annicchiarico and Piano, 2004, Boutonet.al,2005 and Jahufer et.al,2008). Stolons and roots morphology affect white clover persistence through influencing water and nutrients use.
Escaray et.al, 2012, pointed out that many traits enhance genotype's persistence and frequent-cutting tolerance. Among those are; improved nodulation and nitrogen fixation, and soil- salinity or alkalinity tolerance.

The main objectives of the recent study was to determine the correlated responses to selection for frequent-cutting tolerance in barseem clover.

\section{MATERIALS AND METHODS}

200 ecotypes of multi- cut barseem clover were collected from ten governorates (Assuit, Sohage, ElMenia, EL- fayoum, Giza, Khalyobia, Minufenia, Khafr EL- Sheikh, EL- Behira and EL- Sharkia) covering different environments of Egypt. Farmers fields and local markets in each governorate supported ten distinguished ecotypes.

Procedures and methods of materials manipulation and selection during three years period, were performed as stated in Ahmed et el, 2021. During the winter season of 2018/2019, seeds of composite I, composite II, seed mixture of base population and three commercial cultivars namely; Giza 6, Serrow and Helaly were evaluated. Splitplot design with six replicates was used. Main plots were devoted to cutting frequency regimes, whereas, sub-plots represented the evaluated populations. Plot size was six rows, four meters long and $0.2 \mathrm{~m}$ a part. Data were recorded in each cutting for unselected characters as follow; 


\section{1- Growth potentiality:}

$1-1$; Plant height $(\mathrm{cm})$; measured from ground level to the upper most tips in all cuttings.

$1-2$; stem girth $(\mathrm{mm})$; measured as an as anerage of ten plants.

2- Tillering capacity:

2-1; Crown diameter ( $\mathrm{mm})$, determined at last cutting of each cutting regime.

2-2; Number of tillers. plant ${ }^{-1}$ Crown $^{-1}$; determined at last cutting of each cutting regime.

3- Leafiness \%:

$3-1$; leaves weight. plant $^{-1}$; measured as an average of ten plants.

3-2; leaves/stem ratio (fresh weight); determined from dividing fresh weigh of leaves by fresh weight of stems at last cutting of each cutting regime.

Data collected for each set was analyzed as a split- plot according to Cochran and Cox. (1957).

\section{RESULTS AND DISCUSSION}

\section{Growth potentiality}

Growth potentiality, of evaluated populations following to cycles of selection were recorded by the last cuttings in each cutting regime except for, plant height that was measured in all studied cuttings. Studied growth potentiality characters included; plant height $(\mathrm{cm})$, plant fresh weight $(\mathrm{g})$, plant dry weight $(\mathrm{g})$. and stem girth $(\mathrm{mm})$,

\section{Plant height}

Mean squares of plant height for evaluated barseem populations as affected by cutting, cutting regime and their interactions were presented in (Table1). Cuttings gave significantly $(\mathrm{P} \geq 0.01)$ variable plant heights over cutting regimes and populations. Also, the recorded values of plant height were significantly $(\mathrm{P} \geq 0.01)$ different among cutting regimes and among cuttings within different cutting regimes (significant cutting regime $\times$ cutting interaction). Meanwhile, the studied populations significantly $(\mathrm{P} \geq 0.01)$ expressed different plant heights over cuttings and cutting regimes, along with different values for each population in each separate cutting (significant cuttingx population interaction). Neither cutting regime nor cutting $x$ cutting regime gave any significant effects in population's plant height (insignificant interactions among cutting regime $\times$ population and cutting $\times$ cutting regime $\times$ population).

Means of plant height $(\mathrm{cm})$ for evaluated populations under studied cutting frequency regimes were shown in (Table 2). Frequent and very frequent cutting regimes were accompanied with shorter barseem plants in all studied cuttings. The magnitude of reduction in plant height was most pronounced under very frequent cutting regime. Improved populations by selection, for frequent cutting tolerance $\left(\mathrm{C}_{1}\right.$ and $\left.\mathrm{C}_{2}\right)$, showed an increase in plant height by late season cuttings $\left(6^{\text {th }}\right.$ cutting at frequent cutting regime and $6^{\text {th }}$ and $7^{\text {th }}$ cuttings at very frequent cutting regime). The magnitude of improvement in re-growth potentiality, expressed by plant height was sounder for the second cycle of selection $\left(\mathrm{C}_{2}\right)$.

Table 1: Mean squares of plant height for barseem populations as affected by cutting, cutting regime and their interactions.

\begin{tabular}{lcc}
\hline Source of variance & d.f. & Mean Squares \\
\hline Cutting $(\mathrm{C})$ & 6 & $16978.24^{* *}$ \\
\hline Rep / Cutting & 14 & 48.07 \\
\hline Regime $(\mathrm{R})$ & 2 & $5033.19^{* *}$ \\
\hline $\mathrm{C} \times \mathrm{R}$ & 12 & $9383.75^{* *}$ \\
\hline Error & 28 & 37.94 \\
\hline Population $(\mathrm{P})$ & 5 & $524.46^{* *}$ \\
\hline $\mathrm{C} \times \mathrm{P}$ & 30 & $54.28^{*}$ \\
\hline $\mathrm{R} \times \mathrm{P}$ & 10 & $40.02^{\text {n.s }}$ \\
\hline $\mathrm{C} \times \mathrm{R} \times \mathrm{P}$ & 60 & $35.62^{\text {n.s }}$ \\
\hline Error & 210 & 32.75 \\
\hline
\end{tabular}

Correlated realized gains in relation to base population $\left(\mathrm{C}_{0}\right)$ and first cycle of selection $\left(\mathrm{C}_{1}\right)$ for the first and second cycles of selection as plant height were presented in Table (3) and (4). The magnitude of realized gain for the second cycle of selection $\left(\mathrm{C}_{2}\right)$ in each cutting regime was greater than that recorded for the first cycle of selection $\left(\mathrm{C}_{1}\right)$, except for, the very frequent cutting regime that showed negative responses for the former in fifth and seventh cuttings.

Cumulative correlated realized gains over cuttings due to first cycle of selection for frequent cutting tolerance relative to base population $\left(\mathrm{C}_{0}\right)$ reached 2.94, 16.84 and 36.73 percent when evaluated under infrequent, frequent and veryfrequent cutting regimes, respectively. (Table 3). Whereas, the cumulative realized gains over cutting due to the second cycle of selection for frequentcutting tolerance relative to first cycle of selection, reached $44.17,43.02$ and 44.74 percent, when evaluated under infrequent, frequent and very frequent cutting regimes.

It was valuable to notice that, the second cycle of selection for frequent- cutting tolerance gave a reseanable correlated gain in regrowth potentiality reached about 40 percent of the previous cycle.

Cumulative correlated response in plant height due to selection for frequent- cutting tolerance relative to the average of the evaluated check varieties, reached 30.23 and $70.48 ; 30.74$ and 75.75 ; 70.71 and $116.68 \%$ for the first and second cycles of selection when evaluated under infrequent, frequent and very- frequent cutting regimes (Table 4). It is valuable to notice that, the correlated response in growth rate expressed by plant height of successive cuttings were clearly expressed under very frequent cutting regime. 
Table 2: Mean of plant height $(\mathrm{cm}$.) for barseem population under different cutting regimes.

\begin{tabular}{|c|c|c|c|c|c|c|c|c|}
\hline \multirow{2}{*}{ Regim } & \multirow{2}{*}{ Population } & \multicolumn{7}{|c|}{ Means } \\
\hline & & $\mathbf{1}^{\text {st }}$ & $2^{\text {nd }}$ & $3^{\text {rd }}$ & $4^{\text {th }}$ & $5^{\text {th }}$ & $6^{\text {th }}$ & $7^{\text {th }}$ \\
\hline \multirow{8}{*}{ 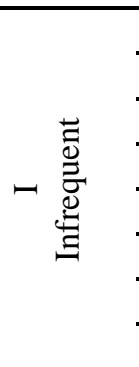 } & Base population $\left(\mathrm{C}_{0}\right)$ & 77.00 & 80.53 & 75.67 & 68.67 & 74.33 & & \\
\hline & Selected population $\left(\mathrm{C}_{1}\right)$ & 75.33 & 63.67 & 77.33 & 69.33 & 87.00 & & \\
\hline & Selected population $\left(\mathrm{C}_{2}\right)$ & 77.67 & 85.93 & 78.33 & 47.00 & 85.33 & & \\
\hline & Checks & & & & & & & \\
\hline & Giza 6 & 72.00 & 64.73 & 74.00 & 63.33 & 74.33 & & \\
\hline & Serrow & 72.67 & 74.37 & 76.33 & 59.00 & 66.00 & & \\
\hline & Hellaly & 73.67 & 80.27 & 74.33 & 61.00 & 72.00 & & \\
\hline & Average & 72.78 & 73.12 & 74.89 & 61.00 & 70.78 & & \\
\hline \multirow{8}{*}{ 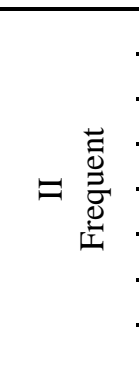 } & Base population $\left(\mathrm{C}_{0}\right)$ & 74.33 & 59.40 & 60.00 & 5933 & 71.00 & 71.00 & \\
\hline & Selected population $\left(\mathrm{C}_{1}\right)$ & 75.33 & 64.17 & 62.67 & 60.00 & 71.69 & 71.00 & \\
\hline & Selected population $\left(\mathrm{C}_{2}\right)$ & 78.33 & 64.67 & 65.00 & 67.33 & 79.67 & 79.67 & \\
\hline & Checks & & & & & & & \\
\hline & Giza 6 & 73.00 & 59.17 & 59.33 & 57.67 & 76.67 & 76.67 & \\
\hline & Serrow & 71.67 & 66.53 & 59.00 & 54.00 & 69.00 & 69.00 & \\
\hline & Hellaly & 74.67 & 53.10 & 58.00 & 55.00 & 63.67 & 63.67 & \\
\hline & Average & 73.11 & 59.60 & 58.78 & 55.56 & 69.78 & 69.78 & \\
\hline \multirow{8}{*}{ 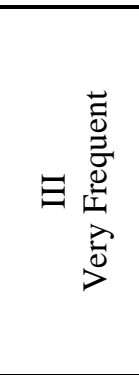 } & Base population $\left(\mathrm{C}_{0}\right)$ & 48.33 & 28.10 & 40.33 & 50.00 & 47.33 & 49.33 & 47.33 \\
\hline & Selected population $\left(\mathrm{C}_{1}\right)$ & 48.33 & 28.73 & 44.67 & 53.33 & 52.33 & 51.00 & 52.33 \\
\hline & Selected population $\left(\mathrm{C}_{2}\right)$ & 50.00 & 33.83 & 43.00 & 61.33 & 51.33 & 55.67 & 51.33 \\
\hline & Checks & & & & & & & \\
\hline & Giza 6 & 48.00 & 63.67 & 37.33 & 50.00 & 48.00 & 48.00 & 48.00 \\
\hline & Serrow & 48.33 & 34.80 & 32.67 & 46.67 & 44.00 & 39.33 & 44.00 \\
\hline & Hellaly & 49.00 & 31.13 & 31.67 & 46.67 & 45.33 & 36.33 & 45.33 \\
\hline & Average & 48.44 & 34.20 & 33.89 & 47.78 & 45.78 & 41.22 & 45.78 \\
\hline L.S.D 0.05 & & & 2.4 & & & & & \\
\hline
\end{tabular}


Table 3: Correlated realized gain (\%) relative to base population $\left(\mathrm{C}_{0}\right)$ and first cycle of selection $\left(\mathrm{C}_{1}\right)$ of plant height for barseem population under different cutting regimes.

\begin{tabular}{|c|c|c|c|c|c|c|c|c|c|c|c|c|c|c|c|}
\hline \multirow{3}{*}{ Regim } & \multirow{3}{*}{ Population } & \multicolumn{14}{|c|}{ Realized gain \% Relative to } \\
\hline & & \multicolumn{7}{|c|}{$\mathbf{C}_{0}$} & \multicolumn{7}{|c|}{$\mathbf{C}_{1}$} \\
\hline & & $\mathbf{1}^{\text {st }}$ & $2^{\text {nd }}$ & $3^{\text {rd }}$ & $4^{\text {th }}$ & $5^{\text {th }}$ & $6^{\text {th }}$ & $7^{\text {th }}$ & $1^{\text {st }}$ & $2^{\text {nd }}$ & $3^{\text {rd }}$ & $4^{\text {th }}$ & $5^{\text {th }}$ & $6^{\text {th }}$ & $7^{\text {th }}$ \\
\hline \multirow{3}{*}{ 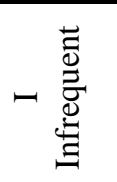 } & Base population $\left(\mathrm{C}_{0}\right)$ & & & & & & & & & & & & & & \\
\hline & Selected population $\left(\mathrm{C}_{1}\right)$ & -2.2 & -20.94 & 2.19 & 0.96 & 17.05 & & & & & & & & & \\
\hline & Selected population $\left(\mathrm{C}_{2}\right)$ & & & & & & & & 3.1 & 34.94 & 1.29 & 6.74 & -1.92 & & \\
\hline \multirow{3}{*}{$=\frac{\overrightarrow{\overrightarrow{0}}}{\overrightarrow{\vec{D}}}$} & Base population $\left(\mathrm{C}_{0}\right)$ & & & & & & & & & & & & & & \\
\hline & Selected population $\left(\mathrm{C}_{1}\right)$ & 1.35 & 8.03 & 4.45 & 1.13 & 0.94 & 0.94 & & & & & & & & \\
\hline & Selected population $\left(\mathrm{C}_{2}\right)$ & & & & & & & & 3.98 & 0.78 & 3.72 & 12.22 & 11.16 & 11.16 & \\
\hline \multirow{3}{*}{ 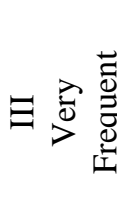 } & Base population $\left(\mathrm{C}_{0}\right)$ & & & & & & & & & & & & & & \\
\hline & Selected population $\left(\mathrm{C}_{1}\right)$ & zero & 2.24 & 3.32 & 6.66 & 10.56 & 3.39 & 10.56 & & & & & & & \\
\hline & Selected population $\left(\mathrm{C}_{2}\right)$ & & & & & & & & 3.46 & 17.75 & 3.19 & 15.00 & -1.91 & 9.16 & -1.91 \\
\hline
\end{tabular}


Table 4: Correlated realized in (\%) relative to the average of checks of plant height for barseem population under different cutting regimes.

\begin{tabular}{|c|c|c|c|c|c|c|c|c|c|c|c|c|c|c|c|}
\hline \multirow{3}{*}{ Regim } & \multirow{3}{*}{ Population } & \multicolumn{14}{|c|}{ Realized gain \% Relative to Checks } \\
\hline & & \multicolumn{7}{|c|}{$\mathbf{C}_{1}$} & \multicolumn{7}{|c|}{$\mathbf{C}_{2}$} \\
\hline & & $\mathbf{1}^{\text {st }}$ & $2^{\text {nd }}$ & $\mathbf{3}^{\text {rd }}$ & $4^{\text {th }}$ & $5^{\text {th }}$ & $\mathbf{6}^{\text {th }}$ & $7^{\text {th }}$ & $\mathbf{1}^{\text {st }}$ & $\mathbf{2}^{\text {nd }}$ & $\mathbf{3}^{\text {rd }}$ & $4^{\text {th }}$ & $5^{\text {th }}$ & $\mathbf{6}^{\mathrm{th}}$ & $7^{\text {th }}$ \\
\hline \multirow{3}{*}{ - } & Base population $\left(\mathrm{C}_{0}\right)$ & & & & & & & & & & & & & & \\
\hline & Selected population $\left(\mathrm{C}_{1}\right)$ & 3.5 & -12.92 & 3.26 & 13.47 & 22.92 & & & & & & & & & \\
\hline & Selected population $\left(\mathrm{C}_{2}\right)$ & & & & & & & & 6.72 & 17.52 & 4.59 & 21.09 & 20.56 & & \\
\hline \multirow{3}{*}{$=\frac{\overrightarrow{0}}{\overrightarrow{0}}$} & Base population $\left(\mathrm{C}_{0}\right)$ & & & & & & & & & & & & & & \\
\hline & Selected population $\left(\mathrm{C}_{1}\right)$ & 3.04 & 7.67 & 6.62 & 7.99 & 2.71 & 2.71 & & & & & & & & \\
\hline & Selected population $\left(\mathrm{C}_{2}\right)$ & & & & & & & & 7.14 & 8.51 & 10.58 & 21.18 & 14.17 & 14.17 & \\
\hline \multirow{3}{*}{ 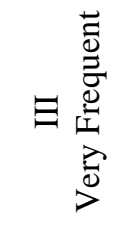 } & Base population $\left(\mathrm{C}_{0}\right)$ & & & & & & & & & & & & & & \\
\hline & Selected population $\left(\mathrm{C}_{1}\right)$ & -0.23 & -15.99 & 22.96 & 11.62 & 14.31 & 23.73 & 14.31 & & & & & & & \\
\hline & Selected population $\left(\mathrm{C}_{2}\right)$ & & & & & & & & 3.22 & -1.08 & 26.88 & 28.36 & 12.12 & 35.06 & 12.12 \\
\hline
\end{tabular}


Ahmed (1992), in a study on barseem clover found that, variations in plant height became strictly limited late in the season, which indicated that, selection based on plant height should be practiced early in the season. Also, he showed that, first cycle of controlled mass selection (C.M.) $\mathrm{C}_{1}$ improved plant height by $8.4 \%$ and $3.2 \%$ over the original population and check variety, respectively. The increase in plant height as a result of (C.M.) $\mathrm{C}_{2}$ selection was less in magnitude. The scored values of increase in plant height from that method were $6.1 \%$ and $10 \%$ over the original population and check variety, respectively. This trend was clearly common in the four studied cuts. The highest increase in plant height was obtained from maternal line selection with $S_{1}$ as a recombinant unit ((M.L) $\mathrm{S}_{1}$ selection method. As an average over cuts (M.L.) $\mathrm{S}_{1}$ selected population exceeded the original population and the check variety by $18.4 \%$ and $12.7 \%$, respectively. He added that, the superiority of (M.L) $\mathrm{S}_{1}$ selection method over the other methods of selection was obvious in most cut. The improvement from (M.L) h.s selection was not different from mass selection procedure in most cuts. As an average over cuts that differences was clear, where $9.4 \%$ and $4.1 \%$ taller plants than the original population and check variety were obtained from (M.L.) h.s selection. Ahmed (2006), evaluated variability in two populations of multi-cut barseem clover. One-hundred and forty four half - sib families from each of Khadarawy and Meskawy multi -cut barseem cultivars were evaluated in two separate experiments. Variability was the highest for plant height. The expected gains from selecting the tallest $10 \%$ of families were 43.46 and $43.02 \%$ for the two populations, respectively. Rajab (2010), practiced selection within 14 populations which selected from 71 populations. Selection was carried out based on plant height $(\mathrm{cm})$. Two cycles of selection within the selected populations resulted in significant differences among the selected plant compared to the original populations.

\section{Stem girth}

Mean squares of stem girth for barseem population as affected by cutting regime and their interaction was presented in Table (5). Stem girth was significantly affected by population $(\mathrm{p} \geq 0.01)$. Barseem's stem girth that resulted from different cutting regimes was insignificantly different. Meanwhile, populations significantly $(p \geq 0.01)$ exhibited different values of stem girth over cutting regimes. The recorded values for barseem's stem girth insignificantly varied among the studied populations in each cutting regime (insignificant $x$ cutting regime $\times$ population interaction).
Table 5: Mean squares of stem girth for barseem populations as affected by cutting regime and their interactions.

\begin{tabular}{lcc}
\hline Source of variance & d.f. & Mean Squares \\
\hline Regimes(R) & 2 & $0.11^{\text {n.s }}$ \\
\hline Error & 10 & 0.07 \\
\hline Population $(\mathrm{P})$ & 5 & $0.48^{\text {*** }}$ \\
\hline $\mathrm{R} \times \mathrm{P}$ & 10 & $0.05^{\text {n.s }}$ \\
\hline Error & 90 & 0.02 \\
\hline \multicolumn{2}{c}{ Values of stem girth for barseem populations }
\end{tabular}
were recorded at the last cutting of each studied cutting regime (Table 6). Because of insignificant interaction between population and cutting regime, the overall means over cutting regimes might be considered. Selected populations exhibited thicker stems with progress of selection cycles, where; 3.44 , 3.89 and $3.00 \mathrm{~mm}$ were obtained for first, second cycles of selection and base populations, respectively. It was valuable to notice that, selected and base populations had significantly thicker stems than any of studied check varieties.

Table 6: Mean of stem girth for barseem population over different cutting regimes.

\begin{tabular}{lc}
\hline Population & Means \\
\hline Base population $\left(\mathrm{C}_{0}\right)$ & 3.00 \\
\hline Selected population $\left(\mathrm{C}_{1}\right)$ & 3.44 \\
\hline Selected population $\left(\mathrm{C}_{2}\right)$ & 3.89 \\
\hline Checks & \\
\hline Giza 6 & 3.33 \\
\hline Serrow & 2.55 \\
\hline Hellaly & 2.88 \\
\hline Average & 2.44 \\
\hline L.S.D. 0.05 & 0.094 \\
\hline
\end{tabular}

Correlated realized gains in stem girth relative to base population $\left(\mathrm{C}_{0}\right)$ and first cycle of selection for frequent cutting tolerance $\left(\mathrm{C}_{1}\right)$ were illustrated in (Table 7). The first cycle of selection for frequentcutting tolerance $\left(\mathrm{C}_{1}\right)$ gave a correlated positive improvement in stem girth reached $15.20 \%$ of the respective base population mean, over cutting regimes. Meanwhile, the second cycle $\left(\mathrm{C}_{2}\right)$ added another positive correlated improvement in stem girth reached $13.12 \%$ of first cycle's mean.

Also, a correlated realized gains in stem girth due to selection for frequent- cutting tolerance relative to the average of check varieties, reached 27.65 and $43.95 \%$ for cycles one and two respectively (Table 7).

\section{Crown diameter $(\mathbf{m m})$ :}

Mean squares of crown diameter for barseem populations as affected by cutting regime and the interaction between population and regime were presented in (Table 8). The recorded values for crown diameter were not significantly different among the studied cutting regimes. 
Table 7: Correlated realized gain $(\%)$ relative to base population $\left(\mathrm{C}_{0}\right)$ and first cycle of $\operatorname{selection}\left(\mathrm{C}_{1}\right)$ and realized gain $(\%)$ relative to the average of checks of stem girth for barseem population under different cutting regimes.

\begin{tabular}{lcccc}
\hline \multirow{2}{*}{ Population } & \multicolumn{2}{c}{$\begin{array}{l}\text { Realized gain (\%) relative to base population } \\
\left(\mathbf{C}_{\mathbf{0}}\right) \text { and first cycle of selection }\left(\mathbf{C}_{\mathbf{1}}\right)\end{array}$} & $\begin{array}{c}\text { Realized gain (\%) relative } \\
\text { to the average of checks }\end{array}$ \\
\cline { 2 - 5 } & $\mathbf{C}_{\mathbf{0}}$ & $\mathbf{C}_{\mathbf{1}}$ & $\mathbf{C}_{\mathbf{1}}$ & $\mathbf{C}_{\mathbf{2}}$ \\
\hline Base population $\left(\mathrm{C}_{0}\right)$ & & & & \\
\hline Selected population $\left(\mathrm{C}_{1}\right)$ & 15.20 & 13.12 & 43.95 \\
\hline Selected population $\left(\mathrm{C}_{2}\right)$ & & & \\
\hline
\end{tabular}

Meanwhile, the evaluated population gave significantly $(\mathrm{p} \geq 0.01)$ variable crown diameters. Also, values of crown diameter that recorded for each population had not significantly varied with changing the applied cutting regime.

Table 8: Mean squares of crown diameter for barseem populations as affected by cutting regime and their interactions.

\begin{tabular}{lcc}
\hline Source of variance & d.f. & Mean Squares \\
\hline Regimes $(\mathrm{R})$ & 2 & $1.43^{\text {n.s }}$ \\
\hline Error & 10 & 0.91 \\
\hline Population $(\mathrm{P})$ & 5 & $10.66^{\text {** }}$ \\
\hline $\mathrm{R} \times \mathrm{P}$ & 10 & $0.60^{\text {n.s }}$ \\
\hline Error & 90 & 0.62 \\
\hline
\end{tabular}

Means of crown diameter (mm) among the evaluated barseem populations over cutting regimes were shown in (Table 9). Selected barseem populations, significantly enjoyed wider crowns (14.66 and $15.56 \mathrm{~mm}$ for the first and the second cycles of selection vs.11.45 $\mathrm{mm}$ for the base population). Also, crown diameter of selected populations, $\left(\mathrm{C}_{1}\right.$ and $\left.\mathrm{C}_{2}\right)$ was significantly wider than the average of evaluated check varieties.

Table 9: Mean of crown diameter (mm) for barseem population over different cutting regimes.

\begin{tabular}{lc}
\hline Population & Means \\
\hline Base population $\left(\mathrm{C}_{0}\right)$ & 11.45 \\
\hline Selected population $\left(\mathrm{C}_{1}\right)$ & 14.66 \\
\hline Selected population $\left(\mathrm{C}_{2}\right)$ & 15.56 \\
\hline Checks & \\
\hline Giza 6 & 12.11 \\
\hline Serrow & 8.67 \\
\hline Hellaly & 8.78 \\
\hline Average & 9.85 \\
\hline L.S.D.0.05 & 0.344 \\
\hline
\end{tabular}

Correlated realized gains in crown diameter following to selection for frequent cutting tolerance in barseem ecotypes reached 26.33 and $20.09 \%$ relative to base population and first cycle of selection, respectively. Meanwhile, relating the realized gains in crown diameter to the average of checks, reached 47.77 and $58.09 \%$ for the first and the second cycles of selection, respectively (Table 10).

Number of tillers:

Mean squares of number of tillers.plant ${ }^{-1}$ for barseem populations as affected by cutting regimes and their interaction were shown in (Table11). Tillers.plant ${ }^{-1}$ were significantly affected by the evaluated cutting frequency regimes. Also, the evaluated populations showed significantly variable number of tillers.plant ${ }^{-1}$. Meanwhile, the recorded tillers.plant $^{-1}$ for each population, significantly varied with each variable cutting regime.

Means of number of tillers.plant ${ }^{-1}$ for barseem populations under different cutting regimes were illustrated in Table 12. Number of tillers.plant ${ }^{-1}$ of selected cycles of barseem were proliferated under infrequent cutting regime $(15.00$ and 15.33 tillers.plant ${ }^{-1}$ for cycle one and cycle two of selection, respectively). Whereas, the least number of tillers. plant ${ }^{-1}$ was expressed under very frequent cutting regime (9.33 and 13.00 tillers.plant $^{-1}$ for $C_{1}$ and $\mathrm{C}_{2}$ of selection, respectively). The frequent cutting regime gave intermediate number of tillers.plant ${ }^{-1}$ (12.67 and 14.67 tillers.plant $^{-1}$ for the two successive cycles, respectively). Check varieties gave significantly lower number of tillers.plant ${ }^{-1}$ under any of the evaluated cutting frequency regimes.

Correlated realized gain $\%$ in number of tillers.plant ${ }^{-1}$ after selection for frequent cutting tolerance relative to base population reached 50.00, 52.10 and $33.29 \%$ after one cycle of selection when evaluated under infrequent, frequent and very frequent cutting regimes respectively. Whereas, the correlated realized gain $\%$ relative to the first cycle of selection were $2.2,15.79$ and $44.44 \%$ after two cycles of selection under the three studied cutting frequency regimes, respectively (Table 13).

Correlated realized gain $\%$ relative to the average of checks after one cycle of selection were $136.9,21.24$ and $39.88 \%$ under the three studied cutting frequency regimes, respectively. After two cycles of selection, the correlated realized gains in number of tillers.plant ${ }^{-1}$ reached 142.2, 40.38 and $94.9 \%$ under infrequent, frequent and very frequent regimes, respectively (Table 14). 
Table 10: Correlated realized gain $(\%)$ relative to base population $\left(\mathrm{C}_{0}\right)$ and first cycle of $\operatorname{selection}\left(\mathrm{C}_{1}\right)$ and realized gain $(\%)$ relative to the average of checks of crown diameter for barseem population over different cutting regimes.

\begin{tabular}{|c|c|c|c|}
\hline \multirow[t]{2}{*}{ Population } & \multirow{2}{*}{ 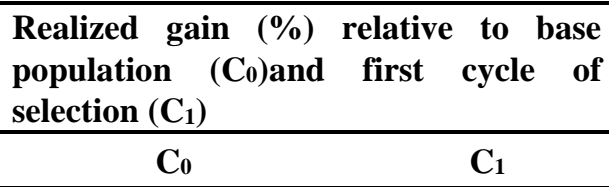 } & \multicolumn{2}{|c|}{$\begin{array}{c}\text { Realized gain }(\%) \text { relative to the } \\
\text { average of checks }\end{array}$} \\
\hline & & $\mathbf{C}_{1}$ & $\mathbf{C}_{2}$ \\
\hline \multicolumn{4}{|l|}{ Base population $\left(\mathrm{C}_{0}\right)$} \\
\hline $\begin{array}{l}\text { Selected population } \\
\left(\mathrm{C}_{1}\right)\end{array}$ & 26.33 & 47.77 & \\
\hline $\begin{array}{l}\text { Selected population } \\
\left(\mathrm{C}_{2}\right)\end{array}$ & 20.09 & & 58.09 \\
\hline
\end{tabular}

Table 11: Mean squares of number of tillers. plant $^{-1}$ for barseem populations as affected by cutting regime and their interactions.

\begin{tabular}{lcc}
\hline Source of variance & d.f. & Mean Squares \\
\hline Regimes $(\mathrm{R})$ & 2 & $5.61^{* *}$ \\
\hline Error & 10 & 0.89 \\
\hline Population $(\mathrm{P})$ & 5 & $12.74^{* *}$ \\
\hline $\mathrm{R} \times \mathrm{P}$ & 10 & $1.84^{* *}$ \\
\hline Error & 90 & 0.76 \\
\hline
\end{tabular}

Table 12: Mean of number of tillers. plant $^{-1}$ for barseem population under different cutting regimes.

\begin{tabular}{|c|c|c|c|c|}
\hline \multirow[b]{2}{*}{ Regim } & \multirow{2}{*}{ Population } & \multicolumn{3}{|c|}{ Means } \\
\hline & & $5^{\text {th }}$ & $6^{\text {th }}$ & $7^{\text {th }}$ \\
\hline \multirow{8}{*}{ - $\underset{\Xi}{\stackrel{\Xi}{\Xi}}$} & Base population $\left(\mathrm{C}_{0}\right)$ & 10.00 & & \\
\hline & Selected population $\left(\mathrm{C}_{1}\right)$ & 15.00 & & \\
\hline & Selected population $\left(\mathrm{C}_{2}\right)$ & 15.33 & & \\
\hline & Checks & & & \\
\hline & Giza 6 & 8.00 & & \\
\hline & Serrow & 6.00 & & \\
\hline & Hellaly & 5.00 & & \\
\hline & Average & 6.33 & & \\
\hline \multirow{8}{*}{ 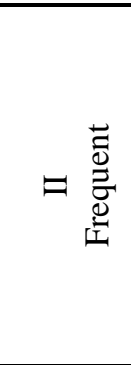 } & Base population $\left(\mathrm{C}_{0}\right)$ & & 8.33 & \\
\hline & Selected population $\left(\mathrm{C}_{1}\right)$ & & 12.67 & \\
\hline & Selected population $\left(\mathrm{C}_{2}\right)$ & & 14.67 & \\
\hline & Checks & & & \\
\hline & Giza 6 & & 13.67 & \\
\hline & Serrow & & 6.00 & \\
\hline & Hellaly & & 11.67 & \\
\hline & Average & & 10.45 & \\
\hline \multirow{8}{*}{ 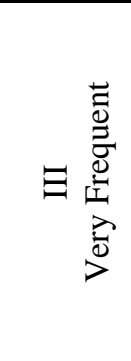 } & Base population $\left(\mathrm{C}_{0}\right)$ & & & 7.00 \\
\hline & Selected population $\left(\mathrm{C}_{1}\right)$ & & & 9.33 \\
\hline & Selected population $\left(\mathrm{C}_{2}\right)$ & & & 13.00 \\
\hline & Checks & & & \\
\hline & Giza 6 & & & 8.00 \\
\hline & Serrow & & & 5.00 \\
\hline & Hellaly & & & 7.00 \\
\hline & Average & & & 6.67 \\
\hline L.S.D 0.05 & & & & \\
\hline
\end{tabular}


Table 13: Correlated realized gain (\%) relative to base population $\left(\mathrm{C}_{0}\right)$ and first cycle of selection $\left(\mathrm{C}_{1}\right)$ of number of tillers.plant ${ }^{-1}$ for barseem population under different cutting regimes.

\begin{tabular}{|c|c|c|c|c|c|c|c|}
\hline \multirow{3}{*}{ Regim } & \multirow{3}{*}{ Population } & \multicolumn{6}{|c|}{ Realized gain \% Relative to } \\
\hline & & \multicolumn{3}{|c|}{$\mathrm{C}_{0}$} & \multicolumn{3}{|c|}{$\mathbf{C}_{1}$} \\
\hline & & $5^{\text {th }}$ & $6^{\text {th }}$ & $7^{\text {th }}$ & $5^{\text {th }}$ & $6^{\text {th }}$ & $7^{\text {th }}$ \\
\hline \multirow{3}{*}{ - } & Base population $\left(\mathrm{C}_{0}\right)$ & & & & & & \\
\hline & Selected population $\left(\mathrm{C}_{1}\right)$ & 50.00 & & & & & \\
\hline & Selected population $\left(\mathrm{C}_{2}\right)$ & & & & 2.2 & & \\
\hline \multirow{3}{*}{ 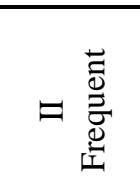 } & Base population $\left(\mathrm{C}_{0}\right)$ & & & & & & \\
\hline & Selected population $\left(\mathrm{C}_{1}\right)$ & & 52.10 & & & & \\
\hline & Selected population $\left(\mathrm{C}_{2}\right)$ & & & & & 15.79 & \\
\hline \multirow{3}{*}{ 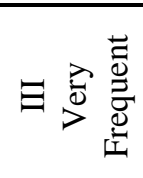 } & Base population $\left(\mathrm{C}_{0}\right)$ & & & & & & \\
\hline & Selected population $\left(\mathrm{C}_{1}\right)$ & & & 33.29 & & & \\
\hline & Selected population $\left(\mathrm{C}_{2}\right)$ & & & & & & 44.44 \\
\hline
\end{tabular}

Table 14: Correlated realized gain $(\%)$ relative to the average of checks of number of tillers.plant ${ }^{-1}$ for barseem population under different cutting regimes.

\begin{tabular}{|c|c|c|c|c|c|c|c|}
\hline \multirow{3}{*}{ Regim } & \multirow{3}{*}{ Population } & \multicolumn{6}{|c|}{ Realized gain \% Relative to Checks } \\
\hline & & \multicolumn{3}{|c|}{$\mathbf{C}_{1}$} & \multicolumn{3}{|c|}{$\mathrm{C}_{2}$} \\
\hline & & $5^{\text {th }}$ & $6^{\text {th }}$ & $7^{\text {th }}$ & $5^{\text {th }}$ & $6^{\text {th }}$ & $7^{\text {th }}$ \\
\hline \multirow{3}{*}{ 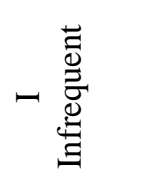 } & Base population $\left(\mathrm{C}_{0}\right)$ & & & & & & \\
\hline & Selected population $\left(\mathrm{C}_{1}\right)$ & 136.97 & & & & & \\
\hline & Selected population $\left(\mathrm{C}_{2}\right)$ & & & & 142.2 & & \\
\hline \multirow{3}{*}{ 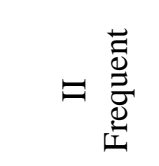 } & Base population $\left(\mathrm{C}_{0}\right)$ & & & & & & \\
\hline & Selected population $\left(\mathrm{C}_{1}\right)$ & & 21.24 & & & & \\
\hline & Selected population $\left(\mathrm{C}_{2}\right)$ & & & & & 40.38 & \\
\hline \multirow{3}{*}{$\exists \frac{\overrightarrow{0}}{>} \frac{\overline{0}}{\overline{0}}$} & Base population $\left(\mathrm{C}_{0}\right)$ & & & & & & \\
\hline & Selected population $\left(\mathrm{C}_{1}\right)$ & & & 39.88 & & & \\
\hline & Selected population $\left(\mathrm{C}_{2}\right)$ & & & & & & 94.90 \\
\hline
\end{tabular}

Ahmed (1992), from a study for the improvement of barseem clover explained to some extent the superiority of some entries in forage production, where, the four high yielding entries exhibited the highest number of branches $/ 0.025 \mathrm{~m}^{2}$. Asmaa Rady (2008), studied morphological and genetic variations in barseem clover. She found that, the magnitude of phenotypic variations in number of branches per plant at the first cutting amounted to about $71 \%$ of first season mean. Whereas, overall seasons, the respective values were $252 \%$ of grand mean. With progress of cutting, phenotypic variation represented lower values of about 7,12 and $6 \%$ of first season, second season and over season's means. Magda Rajab (2010), estimated the variation among some ecotypes of Egyptian clover and response of selection among and within these ecotypes. The phenotypic coefficient of variability (P.C.V) the highest value was possessed by seed yield followed by number of tillers plant ${ }^{-1}$. Awad (2001), studied the genetic variation and response to selection of number of tillers in 5 Egyptian clover cultivars. He reached significant differences between selected populations after one cycle and the base population in number of tillers/ plant.

\section{Leafiness}

Leafiness of barseem populations following to selection for frequent harvest tolerance was traced through measuring leaves weight. plant $^{-1}$ and leaves/ stem ratio (fresh weight). Leafiness characters were measured by last cutting of each practiced cutting frequency regime $\left(5^{\text {th }}, 6^{\text {th }}\right.$ and $7^{\text {th }}$ cutting of infrequent, frequent and very frequent cutting regimes, respectively). 


\section{Leaves weight.plant ${ }^{-1}$ :}

Mean squares of leaves weight.plant ${ }^{-1}$ for barseem populations as affected by cutting regime and their interaction were shown in Table 15 leaves weight. plant ${ }^{-1}$ was significantly affected $(\mathrm{P} \geq 0.01)$ by applied cutting regimes. Also, the magnitude of leaves weight.plant ${ }^{-1}$ among the evaluated populations were significantly $(\mathrm{P} \geq 0.01)$ different. Meanwhile, leaves weight. plant ${ }^{-1}$ for each separate population was significantly $(\mathrm{P} \geq 0.01)$ variable among the applied cutting regimes.

Table 15: Mean squares of leaves weight.plant for barseem populations as affected by cuttings, cutting regime and their interactions.

\begin{tabular}{lcc}
\hline Source of variance & d.f. & Mean Squares \\
\hline Regimes $(\mathrm{R})$ & 2 & $827.45^{* *}$ \\
\hline Error & 10 & 127.32 \\
\hline Population $(\mathrm{P})$ & 5 & $1397.56^{* *}$ \\
\hline $\mathrm{R} \times \mathrm{P}$ & 10 & $279.01^{* *}$ \\
\hline Error & 90 & 57.17 \\
\hline
\end{tabular}

Means of leaves weight.plant ${ }^{-1}$ for barseem populations under different cutting regimes were presented in Table 16. Selection for frequent cutting tolerance gave a substantial improvement in leafiness, indicated by leaves weight.plant ${ }^{-1}$, under each of the tested cutting regimes. Under infrequent cutting regime, 122.67 and 161.67 g.plant ${ }^{-1}$ of leaves were recorded for the first $\left(\mathrm{C}_{1}\right)$ and the second $\left(\mathrm{C}_{2}\right)$ cycles of selection for in frequent cutting tolerance, respectively. Those figures were significantly different from any of the tested check varieties and the average of the checks. Under frequent cutting regimes 124.0 and 153.7 g. plant $^{-1}$ of leaves were recorded for $\mathrm{C}_{1}$ and $\mathrm{C}_{2}$, respectively. Meanwhile, under very frequent cutting regimes, the respective leaves weight.plant ${ }^{-1}$ for the two successive selection cycles were 82.33 and 91.00 g.plant ${ }^{-1}$, respectively. It was valuable to notice that the significant superiority of selected cycles in leaves weight. plant $^{-1}$ over the base population and check variances was extended through the evaluated cutting regimes.

Correlated realized gains in leaves weight. plant ${ }^{-1}$ of the first cycle $\left(C_{1}\right)$ following selection for frequent cutting tolerance, reached 53.34, 106.7 and $31.37 \%$ relative to the base population, when evaluated under infrequent, frequent and very frequent cutting regimes, respectively. Meanwhile, the substantial correlated realized gains after the second cycle of selection reached $31.79,23.93$ and $10.53 \%$ of first cycle's mean, when evaluated under infrequent, frequent and very frequent cutting regimes, respectively (Table 17).

Table 16: Mean of leaves weight.plant ${ }^{-1}$ for barseem population under different cutting regimes.

\begin{tabular}{|c|c|c|c|c|}
\hline \multirow{2}{*}{ Regim } & \multirow{2}{*}{ Population } & \multicolumn{3}{|c|}{ Means } \\
\hline & & $5^{\text {th }}$ & $6^{\text {th }}$ & $7^{\text {th }}$ \\
\hline \multirow{8}{*}{ 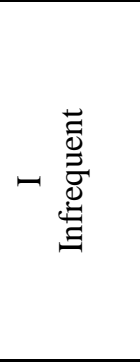 } & Base population $\left(\mathrm{C}_{0}\right)$ & 80.00 & & \\
\hline & Selected population $\left(\mathrm{C}_{1}\right)$ & 122.67 & & \\
\hline & Selected population $\left(\mathrm{C}_{2}\right)$ & 161.67 & & \\
\hline & Checks & & & \\
\hline & Giza 6 & 49.00 & & \\
\hline & Serrow & 52.67 & & \\
\hline & Hellaly & 52.67 & & \\
\hline & Average & 51.45 & & \\
\hline \multirow{8}{*}{ 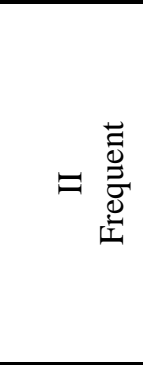 } & Base population $\left(\mathrm{C}_{0}\right)$ & & 60.00 & \\
\hline & Selected population $\left(\mathrm{C}_{1}\right)$ & & 124.00 & \\
\hline & Selected population $\left(\mathrm{C}_{2}\right)$ & & 153.67 & \\
\hline & Checks & & & \\
\hline & Giza 6 & & 46.33 & \\
\hline & Serrow & & 46.33 & \\
\hline & Hellaly & & 86.67 & \\
\hline & Average & & 93.11 & \\
\hline \multirow{7}{*}{$\exists \frac{\overrightarrow{\overrightarrow{0}}}{\stackrel{\overrightarrow{0}}{\overrightarrow{0}}}$} & Base population $\left(\mathrm{C}_{0}\right)$ & & & 62.67 \\
\hline & Selected population $\left(\mathrm{C}_{1}\right)$ & & & 82.33 \\
\hline & Selected population $\left(\mathrm{C}_{2}\right)$ & & & 91.00 \\
\hline & Checks & & & \\
\hline & Giza 6 & & & 56.33 \\
\hline & Serrow & & & 43.00 \\
\hline & Hellaly & & & 46.67 \\
\hline
\end{tabular}


Table 17: Correlated realized gain (\%) relative to base population $\left(\mathrm{C}_{0}\right)$ and first cycle of selection $\left(\mathrm{C}_{1}\right)$ of leaves weight. plant $^{-1}$ for barseem population under different cutting regimes.

\begin{tabular}{|c|c|c|c|c|c|c|c|}
\hline \multirow{3}{*}{ Regim } & \multirow{3}{*}{ Population } & \multicolumn{6}{|c|}{ Realized gain \% Relative to } \\
\hline & & \multicolumn{3}{|c|}{$\overline{\mathrm{C}_{0}}$} & \multicolumn{3}{|c|}{$\mathbf{C}_{1}$} \\
\hline & & $5^{\text {th }}$ & $6^{\text {th }}$ & $7^{\text {th }}$ & $5^{\text {th }}$ & $6^{\text {th }}$ & $7^{\text {th }}$ \\
\hline \multirow{3}{*}{ - } & Base population $\left(\mathrm{C}_{0}\right)$ & & & & & & \\
\hline & Selected population $\left(\mathrm{C}_{1}\right)$ & 53.34 & & & & & \\
\hline & Selected population $\left(\mathrm{C}_{2}\right)$ & & & & 31.79 & & \\
\hline \multirow{3}{*}{ 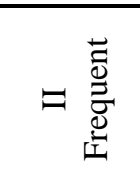 } & Base population $\left(\mathrm{C}_{0}\right)$ & & & & & & \\
\hline & Selected population $\left(\mathrm{C}_{1}\right)$ & & 106.67 & & & & \\
\hline & Selected population $\left(\mathrm{C}_{2}\right)$ & & & & & 23.93 & \\
\hline \multirow{3}{*}{ 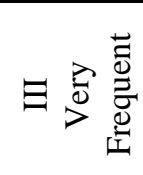 } & Base population $\left(\mathrm{C}_{0}\right)$ & & & & & & \\
\hline & Selected population $\left(\mathrm{C}_{1}\right)$ & & & 31.37 & & & \\
\hline & Selected population $\left(\mathrm{C}_{2}\right)$ & & & & & & 10.53 \\
\hline
\end{tabular}

Correlated realized gains in leaves weight. plant $^{-1}$ relative to the average of the check varieties amounted to $138.4,33.18$ and $48.79 \%$ after one cycle of selection, under the three tested cutting regimes, respectively. Mean while, 214.3, 65.04 and $64.47 \%$ were reached after a second cycle of selection under the three tested cutting regimes, respectively (Table 18).

Leaves/ stem ratio (Fresh weight)

Cutting regimes gave significantly similar leaves/ stem ratio (fresh weight) over the studied barseem population. Also, the differences among the evaluated populations, failed to reach the level of significance. Populations gave similar leaves/ stem ratio irrespective of the used cutting frequency regime (Table 19).
Over the studied cutting regimes, selected populations gave similar leaves/ stem ratio (fresh weight) (27.24 and 30.81 for $\mathrm{C}_{1}$ and $\mathrm{C}_{2}$, respectively). Those values were not different from any of the evaluated check varieties (24.88 to 26.51) (Table 20).

The insignificant correlated realized gains in leaves/ stem ratio (fresh weight) reached 12.05 relative to base population after one cycle of selection and 13.11 relative to the first cycle of selection after two cycles of selection. Also, a positive insignificant correlated realized gains were reached, relative to the average of the studied check varieties $\left(6.45\right.$ and 20.40 for $\mathrm{C}_{1}$ and $\mathrm{C}_{2}$, respectively), (Table 21 ).

Table 18: Realized gain $(\%)$ relative to the average of checks of leaves weight/plant for barseem population under different cutting regimes.

\begin{tabular}{|c|c|c|c|c|c|c|c|}
\hline \multirow{3}{*}{ Regim } & \multirow{3}{*}{ Population } & \multicolumn{6}{|c|}{ Realized gain \% Relative to Checks } \\
\hline & & \multicolumn{3}{|c|}{$\mathbf{C}_{1}$} & \multicolumn{3}{|c|}{$\mathrm{C}_{2}$} \\
\hline & & $5^{\text {th }}$ & $6^{\text {th }}$ & $7^{\text {th }}$ & $5^{\text {th }}$ & $6^{\text {th }}$ & $7^{\text {th }}$ \\
\hline \multirow{3}{*}{ 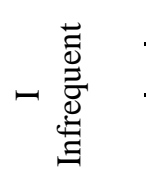 } & Base population $\left(\mathrm{C}_{0}\right)$ & & & & & & \\
\hline & Selected population $\left(\mathrm{C}_{1}\right)$ & 138.43 & & & & & \\
\hline & Selected population $\left(\mathrm{C}_{2}\right)$ & & & & 214.3 & & \\
\hline \multirow{3}{*}{ 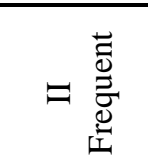 } & Base population $\left(\mathrm{C}_{0}\right)$ & & & & & & \\
\hline & Selected population $\left(\mathrm{C}_{1}\right)$ & & 33.18 & & & & \\
\hline & Selected population $\left(\mathrm{C}_{2}\right)$ & & & & & 65.04 & \\
\hline \multirow{3}{*}{ 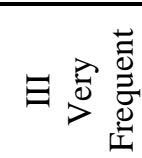 } & Base population $\left(\mathrm{C}_{0}\right)$ & & & & & & \\
\hline & Selected population $\left(\mathrm{C}_{1}\right)$ & & & 48.79 & & & \\
\hline & Selected population $\left(\mathrm{C}_{2}\right)$ & & & & & & 64.47 \\
\hline
\end{tabular}


Table 19: Mean squares of leaves /stem ratio (fresh weight) for barseem populations as affected by cuttings, cutting regime and their interactions.

\begin{tabular}{lcc}
\hline Source of variance & d.f. & Mean Squares \\
\hline Regimes $(\mathrm{R})$ & 2 & $33.14^{\text {n.s }}$ \\
\hline Error & 10 & $11.71^{\text {n.s }}$ \\
\hline Population $(\mathrm{P})$ & 5 & $4.72^{\text {n.s }}$ \\
\hline $\mathrm{R} \times \mathrm{P}$ & 10 & $5.05^{\mathrm{n} . \mathrm{s}}$ \\
\hline Error & 90 & 6.68 \\
\hline
\end{tabular}

Table 20: Mean of leaves /stem ratio (fresh weight) of barseem population over the cutting regimes.

\begin{tabular}{lc}
\hline Population & Means \\
\hline Base population $\left(\mathrm{C}_{0}\right)$ & 24.31 \\
\hline Selected population $\left(\mathrm{C}_{1}\right)$ & 27.24 \\
\hline Selected population $\left(\mathrm{C}_{2}\right)$ & 30.81 \\
\hline Checks & 26.51 \\
\hline Giza 6 & 25.38 \\
\hline Serrow & 24.88 \\
\hline Hellaly & 25.59 \\
\hline Average & n.s. \\
\hline L.S.D.0.05
\end{tabular}

Table 21: Correlated realized gain $(\%)$ relative to base population $\left(\mathrm{C}_{0}\right)$ and first cycle ofselection $\left(\mathrm{C}_{1}\right)$ and realized gain (\%) relative to the average of checks of leaves /stem ratio (fresh weight) for barseem population under different cutting regimes.

\begin{tabular}{|c|c|c|c|}
\hline \multirow[t]{2}{*}{ Population } & \multirow{2}{*}{$\begin{array}{l}\text { Realized gain }(\%) \text { relative to base } \\
\text { population }\left(C_{0}\right) \text { and first cycle of } \\
\text { selection }\left(C_{1}\right) \\
C_{0} \\
\end{array}$} & \multicolumn{2}{|c|}{$\begin{array}{c}\text { Realized gain }(\%) \text { relative to the } \\
\text { average of checks }\end{array}$} \\
\hline & & $\mathbf{C}_{1}$ & $\mathbf{C}_{2}$ \\
\hline \multicolumn{4}{|l|}{ Base population $\left(\mathrm{C}_{0}\right)$} \\
\hline Selected population $\left(\mathrm{C}_{1}\right)$ & 12.05 & 6.45 & \\
\hline Selected population $\left(\mathrm{C}_{2}\right)$ & 13.11 & & 20.40 \\
\hline
\end{tabular}

Ahmed (1992), in a study on barseem clover found that, controlled mass selection (C.M) $\mathrm{C}_{1}$ improved leaf/stem ratio in the second cutting. That improvement reached $6.5 \%$ and $11.1 \%$ over the original population and the check variety, respectively. As an average over cuts, that method of selection resulted in an increase of $1.1 \%$ and $4.4 \%$ in leaf/stem ratio over the original population and check variety, respectively. While, the improvement in leaf/stem ratio from selection was in general not significantly different among selection methods, in the second cut as well as seasonal average, maternal line selection with $S_{1}$ as recombinant (M.L) $\mathrm{S}_{1}$ selection method ranked the first, where $3.4 \%$ and $6.7 \%$ increases in leaf/stem ratio were obtained as an average over original population and check variety. Rajab (2010),), from a study on some Egyptian clover entries obtained value of expected genetic advance of 8.07 for leaf/stem ratio. Also, she practiced selection within 14 populations which were selected from 71 populations. Evaluation of the two selected generations, revealed that seven population exceeded the local variety (Giza-6) and other selected populations in leaf/stem ratio. frequent-cutting tolerance is considered as a complex character that includes many morphological and physiological traits, along with their interactions with environment (KatepaMupondwa et.al, 2002). Moreover, it is well know that selection for one trait or many traits related to frequent- cutting tolerance might lead to reduction of productivity and loss or other quality characters (Smith et.al, 2000).In whiteclover "Trifoliumrepens, L."Frequent-cutting tolerant genotype had morphological character correlated with stolon diameter, branching potentiality, leaf size and root structure (Ayres et.al,1996; Jahufer et.al,2002, Sanderson et.al,2003, Annicchiarico and Piano, 2004, Bouton et.al,2005 and Jahufer et.al, 2008). Stolons and roots morphology affect white clover persistence through influencing water and nutrients use. Taylor (2008) described legume forage persistence (continuous productivity irrespective of frequent cutting) as a result of interaction between adaptive potentialities of genotype and stress condition that result in a level of stress tolerance. So, all breeding effects to acquire tolerance to stresses (climatic, edaphic or biotic) are trials to reach plant potentiality to reach tolerance and 
persistence. Many researchers attempted to reach that, among them Taylor,2008 on red clover "Trifolium pretense, L". Annicchiarico, 1997 and Widdup and Barret, 2011 on white clover "Trifoliumrepens, L" and Smith et.al, 2000 and Bouton, 2012 on alfalfa "Medicago sativa, L."

\section{SUMMARY AND CONCLUSION}

\section{Plant height}

Cumulative correlated realized gains over cuttings due to first cycle of selection for frequent cutting tolerance relative to base population $\left(\mathrm{C}_{0}\right)$ reached 2.94, 16.84 and 36.73 percent when evaluated under infrequent, frequent and veryfrequent cutting regimes, respectively.

1-The cumulative realized gains over cutting due to the second cycle of selection for frequent cutting- tolerance relative to first cycle of selection, reached 44.17, 43.02 and 44.74 percent, when evaluated under infrequent, frequent and very frequent cutting regimes.

2-Cumulative correlated response in plant height due to selection for frequent- cutting tolerance relative to the average of the evaluated check varieties, reached 30.23 and $70.48 ; 30.74$ and $75.75 ; 70.71$ and $116.68 \%$ for the first and second cycles of selection when evaluated under infrequent, frequent and very- frequent cutting regimes.

3-It is valuable to notice that, the correlated response in growth rate expressed by plant height of successive cuttings were clearly expressed under very frequent cutting regime.

\section{Stem $\operatorname{girth}(\mathbf{m m})$ :}

4-Selected populations exhibited thicker stems with progress of selection cycles, where; 3.44, 3.89 and $3.00 \mathrm{~mm}$ were obtained for first, second cycles of selection and base populations, respectively. It was valuable to notice that, selected and base populations had significantly thicker stems than any of studied check varieties.

Tillering capacity:

\section{Crown diameter (mm):}

5-Selected barseem populations, significantly enjoyed wider crowns (14.66 and $15.56 \mathrm{~mm}$ for the first and the second cycles of selection $v s .11 .45 \mathrm{~mm}$ for the base population). Also, crown diameter of selected populations, $\left(\mathrm{C}_{1}\right.$ and $\mathrm{C}_{2}$ ) was significantly wider than the average of evaluated check varieties.

6-Correlated realized gains in crown diameter following to selection for frequent cutting tolerance in barseem ecotypes reached 26.33 and $20.09 \%$ relative to base population and first cycle of selection, respectively. Meanwhile, relating the realized gains in crown diameter to the average of checks, reached 47.77 and
$58.09 \%$ for the first and the second cycles of selection, respectively.

Number of tillers.plant ${ }^{-1}$ :

7-Correlated realized gain $\%$ in number of tillers.plant ${ }^{-1}$ after selection for frequent cutting tolerance relative to base population reached $50.00,52.10$ and $33.29 \%$ after one cycle of selection when evaluated under infrequent, frequent and very frequent cutting regimes respectively. Whereas, the correlated gain\% relative to the first cycle of selection were 2.2, 15.79 and $44.44 \%$ after two cycles of selection under the three studied cutting frequency regimes, respectively.

8-Correlated realized gain $\%$ relative to the average of checks after one cycle of selection was $136.9,21.24$ and $39.88 \%$ under the three studied cutting frequency regimes, respectively. After two cycles of selection, the correlated gains in number of tillers.plant ${ }^{-1}$ reached 142.2, 40.38 and $94.9 \%$ under infrequent, frequent and very frequent regimes, respectively.

\section{Leafiness}

Leaves weight.plant ${ }^{-1}$ :

9-Correlated realized gains in leaves weight. plant $^{-1}$ of the first cycle $\left(C_{1}\right)$ following selection for frequent cutting tolerance, reached 53.34, 106.7 and $31.37 \%$ relative to the base population, when evaluated under infrequent, frequent and very frequent cutting regimes, respectively. Meanwhile, the substantial correlated gains after the second cycle of selection reached $31.79,23.93$ and $10.53 \%$ of first cycle's mean, when evaluated under infrequent, frequent and very frequent cutting regimes, respectively.

10- Correlated realized gains in leaves weight. Pla`

Q232nt ${ }^{-1}$ relative to the average of the check varieties amounted to $138.4,33.18$ and $48.79 \%$ after one cycle of selection, under the three tested cutting regimes, respectively. Mean while, 214.3, 65.04 and $64.47 \%$ were reached after a second cycle of selection under the three tested cutting regimes, respectively.

Leaves/ stem ratio (Fresh weight):

11- An insignificant correlated realized gains in leaves/ stem ratio (fresh weight) reached 12.05 relative to base population after one cycle of selection and 13.11 relative to the first cycle of selection after two cycles of selection. Also, positive insignificant correlated realized gains were reached, relative to the average of the studied check varieties (6.45 and 2040 for $\mathrm{C}_{1}$ and $\mathrm{C}_{2}$, respectively). 


\section{REFERENCES}

Ahmed, M. Abd EL- Sattar, 1992. Improvement of barseem clover (Trifolium alexandrinum L.) by different methods of selection. Ph.D. Thesis, Faculty of Agriculture, Alexandria University, Egypt.

Ahmed, M. Abd EL- Sattar, 2006. Response to three methods recurrent selection in a Khadarawi barseem (Trifolium alexandrinum L.) population. Alex. J. Agric. Res., 51: 13-23.

Ahmed, M. Abd EL- Sattar,Asmaa M. S. Rady,T. K. Abd ElAzize, and W.M. Eldebeky.2021. Selection for frequent cutting tolerance among Egyptian ecotypes of barseem clover" Trifolium alexandrinum L.".J.of Plant Production, Mansoura Univ.,12(3); 305-3012.

Annicchiarico,P., and E. Piano. 2004. Indirect selection for root development of white clover and implications for drought tolerance. Journal of Agronomy and Crop Science, 190, 28-34.

Annicchiarico, P. 1997. Indirect selection for persistence and seed yield in large- leaved white clover. Plant Breeding, 116, 192-194.

Annicchiarico, P., C. Scotti, M. Carelli and L. Pecetti. 2010. Questions and avenues for Lucerne improvement. Czechj.Genet. Plant Breed. 46: 1-13.

Awad, I.M.H. 2001. Evaluation of some Upper Egyptian barseem clover (Trifolium alexandrinum, L.), M.Sc. thesis, Fac. Agric. Assiut Univ; Egypt.

Ayres J., J. Caradus, L. Lane, and R. Murisos. 1996. White clover breeding for dryland sheep and cattle pastures in Australia. In Woodfield (ed) White clover: New Zealand's Competitive Edge PP. 155-158.

Bouton J. 2012. Breeding Lucerne for persistence.Crop \& Pasture Science, 93, 95106.

Bouton J., D. Woodfield, C. Hoveland, M. Mccann and J. Caradus 2005. Enhanced survival and animal performance from ecotype derived white clover cultivars. Crop Science, 45, 1596-1602.

Cochran, W.G. and G.M. Cox. 1957. Experimental Designs. Wiley, New York.
Escaray, F., A. Menendez, A. Garriz, F. pieckenstain, M. Estrella, L. Castagno, P. Carrasco, J. Sanjuan, and O. Ruiz. 2012. Ecological and agronomic importance of the plant genous lotus. Its application in grassland sustainability and the amelioration of constrained and contaminated soils-Plant Science 182; 121-133.

Jahufer M., M. Cooper, J. Ayres, and R. Bray. 2002. Identification of research to improve the efficiency of conventional breeding strategies for white clover in Australia. Australian Journal of Agricultural Research, 53, 239-257.

Jahufer M., S. Nichols, R. Crush, L. Ouyang, A. Dunn, J. Ford, D. Care, A. Griffiths., C.S. Jones, and C.G. Jones 2008.Genotypic variation for root trait morphology in a white clover mapping population grown in sand. Crop Science, 48, 487-494.

Katepa-Mupondwa, F., A. Singh, S. Smith JR., and W. Mc-caughey. 2002. Grazing tolerance of alfalfa (Medicago spp.) under continuous and rotational stocking systems in pure stands and in mixture with meadow brome grass (Bromus riparius Rehm. Syn. B. biebersteinit Roem\&schult). Canadian J. PL. Sci. 82, 337347.

Rady, A.M.S. (2008). Estimation of morphological and genetic variations in berseem clover gene pool. M.Sc.Thesis, Crop Sci. Dept., Fac. Agric., Alex. Univ. Egypt.

Rajab, M.N. (2010). Studies on breeding of Egyptian clover (Trifolium alexandrinuma, L.). Ph.D. Thesis, Fac. Agric. Minia Univ., Egypt.

Sanderson M., R. Byers, R. Skinner, and G. Elwinger 2003. Growth and complexity of white clover stolons in response to biotic and abiotic stress. Crop Science, 43, 2197-2205.

Sewell J., R. Hill, and J. Reich. 2011. Persistence of grazing tolerant lucerne under Australian conditions. Pasture Persistence, Grassland Research and Practice Series, 15, 187-190.

Smith, S., J. bouton, A. Singh and W. Mccaughey. 2000. Development and evaluation of grazingtolerant alfalfa cultivars; A review. Cand. J. PL. Sci. 80 (3); 503-512.

Taylor N. 2008. A century of clover breeding developments in the United States. Crop Science, 48, 1-13.

Widdup, K., and B. Barrett. 2011. Achieving persistence and productivity in white clover pasture persistence. Grassland research and practice series (15); 153-180. 


\title{
الملخص العربى
}

\section{الاستاجابات المرتبطه فى صفات كفاءة النمو والقدره على التفريع وكفاعة الاوراق فى البرسيم المصرى" Lrifolium alexandrium, L" بعد الاتخخاب لتحمل الحش المتكرر}

\author{
محمد عبد الستار احمد'، اسماء محمد سميز راضى'، طارق كامل عبد العزيز׳ ووليد محمد الابيكى' \\ ' كلية الزر اعه جامعة الاسكندريه. \\ r قسم بحوث العلف، مركز البحوث الزر اعيه، وزارة الزر اعه واستصلاح الار اضى.
}

الهدف الرئيسي للاراسة الحالية تتضمن تمييز الطرز البيئيه من البرسيم المصرى ذات الإستجابات المرتبطة

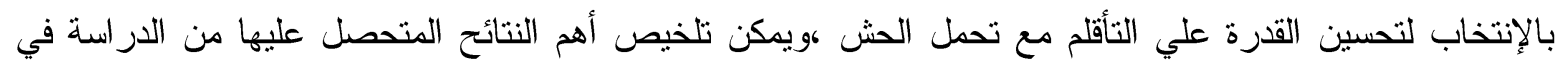
الآتي:

ا- الإستجابة المرتبطة المجمعة في إرتفاع النبات بعد الدورة الاولى من الإنتخاب منسوبة إلي عثيرة الدورة

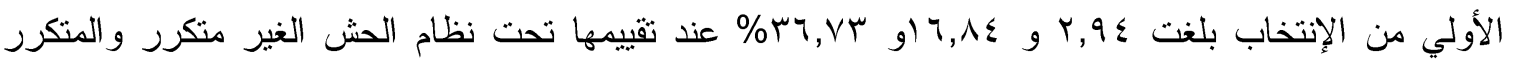
وشديد التكرار، علي التزتيب. ץ- الدوره الاولى من الانتخاب لتحمل الحش المتكرر نتج عنها تحسن متلازم موجب في صفئ سمك الساق بلغ 10, 10 \% من منوسط عشيرة الاساس، كمنوسط عام لنظم الحش المختبرة.

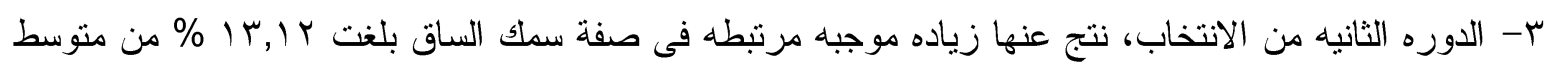

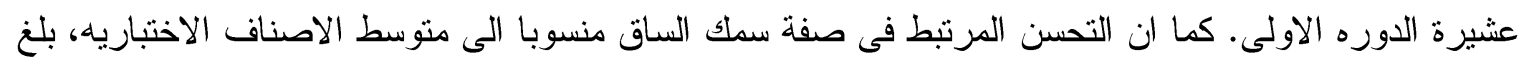

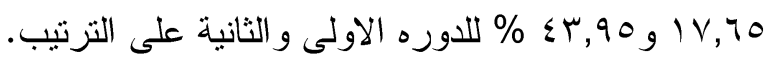

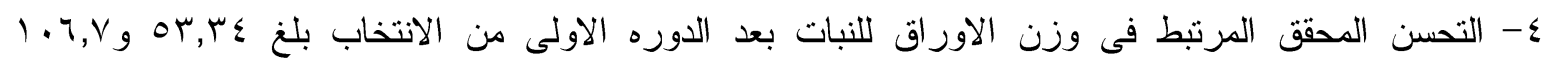

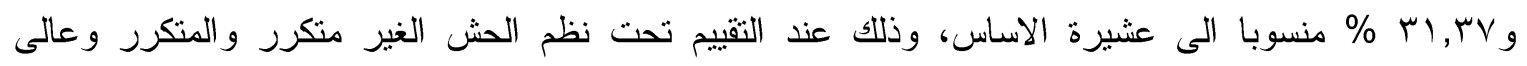

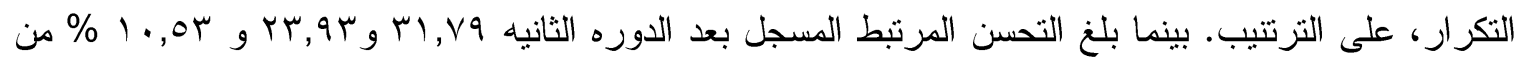

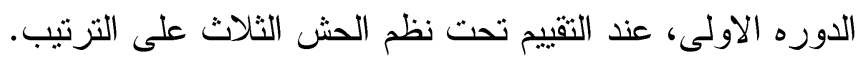

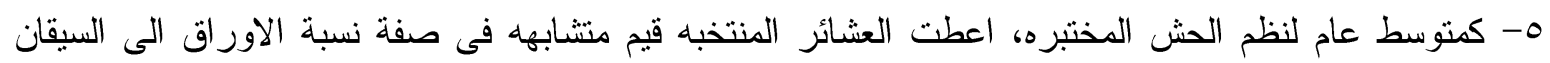

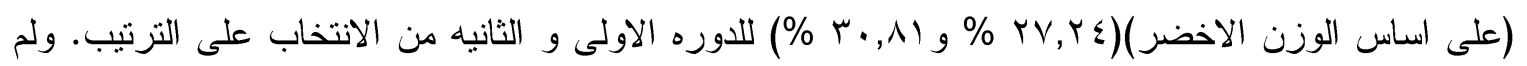
تختلف تلك القيم عن أي من الاصناف الاختبارية. 